A monthly newsletter dedicated to the unique interests in microscopy and published, at no cost, to some 11,000 professionals in North America.

Don Grimes, Editor

\title{
INDUSTRY nEUS
}

Congrats to New MSA Officers;

President-Elect: Robert Cardell

Treasurer: Ron Anderson

Director, Biological: Ralph Albrecht

Director, Physical: Linda Horton

$\checkmark$ Registration Bulletins and Call for Papers booklets for the 1993 MSA Conference are available: Tel: (800)538-3672, Fax: (508)548-9053.

Fifth International

Conference for

scanning microscopists ...

\section{SCANNING 93}

at

Twin Towers Hotel and Convention Center Orlando, Florida, USA

April 21 to 23,1993

featuring distinguished plenary speakers,

3 full days of concurrent sessions,

workshops, mini-short courses, student program awards, tutorials, and exhibits

All Day Confocal Microscopy Workshop and Welcome Reception

Tuesday, April 20

Phone (201-818-1010) or fax (201-818-0086) now for full program and travel information, and all the forms you need to register. Attention: Mary K. Sullivan

Sponsored by the

Foundation for Advances in

Medicine and Science (FAMS)

Box 832, Mahwah, NJ 07430-0832, USA $\checkmark$ The Senate has passed Legislation S. 654 which ensures patent protection for innovative biotechnology processes - which is further defined as "any method of making or using living organisms, or parts thereof, for the purpose of making or modifying products". It includes recombinant DNA, recombinant RNA, cell fusion including hybridoma techniques, and other processes involving site-specific manipulation of genetic material. It further provides protection against the import of products made using a biotechnological material that is patented in the U.S.

$\checkmark$ The American Vacuum Society (AVS) is creating an electronic database of all spectra of solid surfaces having technological and scientific interest. Spectroscopic submissions received from surface scientists, if accepted, will be archived in the new database. The database will be supported by the new journal, Surface Science Spectra. Digitalized versions of the spectra will be available to subscribers on disk. Subscription information is available from the American Institute of Physics, Member \& Subscriber Service, 500 Sunnyside Blvd., Woodbury, NY; phone (516)576-2270, Fax (516)349-9704.

$\checkmark$ A new Center for Advanced Manufacturing Technology at Sandia National Laboratories in New Mexico and California has been announced by the Department of Energy. The facilities capabilities will include advanced materials and processes, microelectronics, intelligent machines for hazardous operations, sensors and controls, joining technologies, and "environmentally conscious processes".

John Benson, Joe Mullen and Dennis Masaki, all until recently with Noran Instruments have joined Radiation Mesurements, Inc.
Two New BBSs

1) From the Argonne National Laboratory, "NEWTON" is a bulletin board system designed for both science teachers and students. It contains services such as calendars of conferences and workshops, ideas for classroom demonstrations, and Argonne publications on science, technology, and education. Students and teachers can leave questions to be answered by scientists, exchange computer files and software, or just chat with like-minded folks. Access is by phone at (708)252-8241.

2) Oxford Instruments, Canada, has introduced a BBS with a microscopy theme. File areas include a selection of shareware programs available for downloading, DOS utilities, image processing and graphics processing, windows utilities and communication programs. Also available are newsletter updates and EM related bulletin information. Planned are file areas for information exchange and "advice" on a number of EM and EDS topics and, hopefully, email and " 800 " number service. All are welcome! Phone access at (416)568-1766, 2400-9200 baud, 8 data bits, 1 stop bit, and no parity.

$\checkmark$ The Venezuelan Society for Electron Microscopy (SVME) has launched a new journal devoted to research and review papers covering all aspects of microscopy. Dr. Susan Tai of the University of the Orient in Comana is Editor-inChief and is supported by Drs. Mariana Staia and Antonio Bretana as Principal Editors. Volume 1 for 1992 contained 21 articles in 220 pages - with excellent micrograph reproduction. Requests for sample copies and enquiries regarding submission of manuscripts should be sent to Dr. Susan Tai, Acta Microscopia, IIBCA Universidad de Oriente, Cumana, Estado Sucre, Venezuela (Fax 58-2-731-34-18) 